\title{
Screening Carrot Germplasm for Resistance to Xanthomonas hortorum
}

\section{pv. carotae}

\author{
Charles E. Christianson, Stephen S. Jones, and Lindsey J. du Toit ${ }^{\mathbf{1}}$ \\ Washington State University Mount Vernon Northwestern Washington \\ Research \& Extension Center 16650 State Route 536, Mount Vernon, WA \\ 98273-4768
}

Additional index words. bacterial blight, Daucus carota, U.S. Department of Agriculture National Plant Germplasm System

\begin{abstract}
Xanthomonas hortorum pv. carotae (Xhc) causes bacterial blight of carrot (Daucus carota $\mathrm{L}$.), is endemic in the primary regions of carrot seed production, and is readily seed-transmitted. Genetic resistance to $X h c$ is not well documented in commercially available carrot cultivars, and there has been little public research on screening for resistance. Carrot PI lines $(n=66)$, public inbred lines $(n=2)$, and commercial cultivars $(n=17)$ were assessed for response to $X h c$ in a greenhouse in 2012 based on the incidence and severity of bacterial blight symptoms after inoculation as well as Xhc population [colony-forming units (CFU)/g dry foliage] detected by dilution plating onto XCS agar, a semiselective medium for Xhc. Severity of bacterial blight averaged $8.8 \% \pm 0.4 \%$ (mean \pm SE) with a range of $0 \%$ to $50 \%$, and size of the $X h c$ population detected on the foliage averaged $8.16 \times 10^{9} \pm 1.07 \times 10^{9} \mathrm{CFU} / \mathrm{g}$ (range, $1.38 \times 10^{4}$ to $\left.3.28 \times 10^{11} \mathrm{CFU} / \mathrm{g}\right)$ for individual plants. Eight putative resistant PI lines and five highly susceptible PI lines selected from the 2012 screening were evaluated again in 2013 with an additional two PI lines, 12 cultivars, two inbred lines, and 12 carrot wild relatives. In the 2013 trial, severity of foliar blight 6 weeks post-inoculation ranged from $0 \%$ to $90 \%(11.8 \% \pm 0.4 \%)$, and $X h c$ population ranged from $4.90 \times 10^{4}$ to $1.30 \times 10^{11} \mathrm{CFU} / \mathrm{g}$ dry foliage $\left(1.00 \times 10^{10} \pm 5.29 \times 10^{8}\right.$ $\mathrm{CFU} / \mathrm{g}$ ) for individual plants. Spearman's correlation coefficient between the Xhc population detected and severity of bacterial blight was highly significant in the 2012 and 2013 trials $(r=0.52$ and 0.62 , respectively, at $P<0.0001)$. PI lines 418967,432905 , and 432906 were the most resistant based on Xhc population detected and could be used to develop resistant cultivars. Of the 12 carrot wild relatives screened, only Ames 7674 and SS10 OR displayed a relatively low severity of bacterial blight and population of $X h c$ on the foliage.
\end{abstract}

In 2013, carrot (Daucus carota) root crops were grown on greater than 29,000 ha in the United States at a value of $\$ 655$ million [U.S. Department of Agriculture National (USDA) Agricultural National Statistics Service, 2014]. In addition, carrot seed growers in the semiarid,

Received for publication 3 Dec. 2014. Accepted for publication 15 Jan. 2015

This work was supported with funding from Bejo Seeds, Inc.; the Columbia Basin Vegetable Seed Association; and PPNS No. 0678, Department of Plant Pathology, College of Agricultural, Human, and Natural Resource Sciences Agricultural Research Center, Hatch Project No. WNP 00595, Washington State University, Pullman, WA. In-kind support was provided by Bayer CropScience Vegetable Seeds, Osborne International Seed Co., LLC; and Nash Huber, Huber Farms. Resources were also provided by Hatch Multistate Project NC-7 and the U.S Department of Agriculture-Agricultural Research Service, North Central Regional Plant Introduction Station, Iowa State University, Ames, IA.

We thank Mike Derie, Barbara Holmes, and Sarah Meagher for technical support; and Peter Rogers, Bayer CropScience Vegetable Seeds; Scot Hulbert, Washington State University; and Irwin Goldman, University of Wisconsin, for reviewing the manuscript and providing technical advice.

${ }^{1}$ To whom reprint requests should be addressed; e-mail dutoit@wsu.edu. inland Pacific Northwest (Idaho, Oregon, and Washington) produced greater than $50 \%$ of the world supply of carrot seed and $\approx 85 \%$ of the U.S. carrot seed supply on $\approx 3100$ ha in the 2011-12 biennial season for seed production at an estimated value of $\$ 5$ million to $\$ 15$ million (Butler and Simmons, 2012; Washington State Commission on Pesticide Registration, 2011). Xanthomonas hortorum pv. carotae causes bacterial blight of carrot (Gilbertson, 2002). Bacterial blight reduces the photosynthetic leaf area and can hinder harvest when the roots are pulled from the soil by foliage, the most common method of harvesting fresh market carrots in the United States, if the petioles are weakened by the disease (du Toit et al., 2005; Gilbertson, 2002; Pfleger et al., 1974; Rogers et al., 2011). Xhc also can affect carrot seed crops by blighting umbels and foliage, reducing seed yield, and infesting developing seed (du Toit et al., 2005; Gilbertson, 2002).

The bacterial blight pathogen is spread long distances on infested seed but may also spread within a carrot crop or growing region by splashing water (precipitation or irrigation) as well as on machinery, insects, or people moving through infected carrot crop canopies (Gilbertson, 2002). Carrot seed crops are direct-seeded (seed-to-seed) or grown from vernalized roots produced in locations such as southern California or Arizona (root-to-seed) (Rubatzky et al., 1999). Consecutive, directseeded carrot seed crop seasons overlap by 4 to 8 weeks in the Pacific Northwest, resulting in a "green bridge" effect that facilitates movement of pathogens and pests among crops. This has contributed to the endemic presence of $X h c$ in this primary carrot seed production region of the United States, where the bacterium is readily disseminated on dry, aerosolized foliage produced during threshing of mature, infected carrot seed crops that is blown onto newly planted carrot seed crops for the next biennial season (du Toit et al., 2005).

Infested carrot seed lots can be treated with hot water or disinfectants, e.g., trisodium phosphate or sodium hypochlorite, to eradicate or significantly reduce $X h c$ populations on seed (du Toit et al., 2005, in press; Temple et al., 2013). However, such seed treatments are resource-intensive, particularly considering the volumes of seed to be treated, and may reduce vigor and shelf life of carrot seed lots. Therefore, production of carrot seed lots free of $X h c$ is preferable to large-scale treatment of carrot seed.

Chemical management options for bacterial blight during the growing season are limited primarily to protective applications of copper-based formulations. However, because symptoms of bacterial blight are not expressed on carrot foliage until Xhc populations reach greater than $10^{5} \mathrm{CFU} / \mathrm{g}$ dry foliage, and copper bactericides have no curative activity, applications made after the appearance of bacterial blight symptoms are largely ineffective, particularly over the 13- to 14-month duration of seed crops (du Toit et al., 2005; Gilbertson, 2002). du Toit and Derie $(2005,2008 \mathrm{a}, 2008 \mathrm{~b})$ and du Toit et al. (2006) demonstrated that preventive applications of bactericides (e.g., copper hydroxide) can reduce development of Xhc significantly on carrot foliage, but effective control could not be achieved when applications were made after the pathogen had established on carrot foliage (du Toit and Derie, 2008a). Combining copper-based application strategies with cultural practices such as the use of drip irrigation to reduce periods of leaf wetness, incorporating crop residues into the soil after harvest to facilitate residue decomposition and a decline in $X h c$ inoculum in the soil, and a minimum 3-year rotation between carrot crops have assisted producers in reducing the negative impact of Xhc (Crowe et al., 2005). However, additional management options based on genetic resistance to the pathogen are needed

Xhc has had a significant impact on the carrot industry at times, yet there has been little public research to identify genetic resistance to this pathogen and no commercial carrot cultivars currently are marketed as resistant to bacterial blight (Boiteux and Simon, 2002; Gugino et al., 2004). Pfleger et al. (1974) demonstrated that the degree of susceptibility to bacterial blight varies among carrot accessions. In addition, recent evidence 
of the presence in the $X h c$ genome of orthologs of Type III effector genes as well as homologs of $h r p$ genes that can trigger hypersensitive responses in plants to bacterial pathogens (Kimbrell et al., 2011; Leite et al., 1994) indicates it may be possible to breed for greater resistance to bacterial blight than the resistance currently available in commercial cultivars. Carrot grower demand for $X h c$-free seed has superseded the necessity for bacterial blight-resistant cultivars, and recent development of thresholdbased approaches to $X h c$ management in root crops (Umesh et al., 1998) have highlighted the need for a greater understanding of the influence of carrot accession on development of bacterial blight.

The USDA National Plant Germplasm System (NPGS) has 1370 accessions of Daucus spp. collected from 64 countries (Reitsma and Clark, 2013). The accessions have been used to identify resistance to carrot fly, which has been incorporated into commercial germplasm (Ellis, 1999). This germplasm could offer sources of resistance to other carrot pests and pathogens, including $X h c$. Therefore, the objectives of this research were to: 1) identify potential source(s) of genetic resistance to $X h c$ from a subset of Daucus germplasm from the USDA NPGS; and 2) correlate visual ratings of bacterial blight severity of this germplasm collection with the size of the $X h c$ population detected on foliage of these accessions to determine the efficiency of selecting for resistance to $X h c$ based on foliar symptoms, because this is far less time- and resource-expensive than quantifying Xhc populations (Christianson, 2014).

\section{Materials and Methods}

2012 trial. Two hundred seeds of each of 66 carrot PI lines were obtained from the USDA NPGS (Table 1). These PI lines were selected based on results of a preliminary screening provided by a carrot breeder from a commercial seed company (data not shown, proprietary information). The PI lines that appeared most resistant or most susceptible to bacterial blight, Alternaria leaf blight (caused by Alternaria dauci) and/or Cercospora leaf spot (Cercospora carotae), were selected from the preliminary screening. Two inbred malesterile carrot lines (A2566 and A0493) from Dr. Philip Simon's USDA Agricultural Research Service (ARS) carrot breeding program at the University of Wisconsin were included in the screening. Commercial carrot cultivars from Bejo Seeds, Inc. (Oceano, CA); Nunhems USA, Inc. (now Bayer CropScience Vegetable Seeds, Brooks, OR); Sakata Seed America (Burlington, WA); and Monsanto Vegetable Seeds, Inc. (Woodland, CA) were obtained from seed company representatives or breeders as well as Osborne International Seed Co., LLC (Mount Vernon, WA) to compare results for the PI lines to those of widely grown carrot cultivars in the United States and cultivars that represent a diversity of carrot types (Rubatzky et al., 1999).

In Sept. 2012, carrot seeds of each accession were planted in the greenhouse in RediEarth Starter Medium (SunGro Horticulture, Vancouver, BC, Canada) in PL-72 standard plug trays (T.O. Plastics, Otsego, MN). As a result of concerns that hot water treatment can reduce seedling vigor and the very limited amount of seed of each PI line provided, seed of each PI line was not hot water-treated to eradicate any potential seedborne $X h c$. Each flat was filled with potting mix and imbibed in fertigated water $(20 \mathrm{~N}-$ 20P-20K) calibrated to provide $200 \mathrm{ppm}$ nitrogen. Seeds were planted (one seed/cell) at a depth of $0.5 \mathrm{~cm}$ and the flats watered. Carrot plants were grown with a 10 -h photoperiod at $26 / 25^{\circ} \mathrm{C}$ by day/night and fertigated as needed. Insect pests were controlled with a weekly spray of acephate (Orthene Turf, Tree, and Ornamental Spray 97; Amvac Chemical Corp., Los Angeles, CA), spinosad (Entrust Naturalyte Insect Control; Dow AgroScience LLC, Indianapolis, IN), imidacloprid (Leverage 2.7; Bayer CropScience LP, Research Triangle Park, NC), or Beauvaria bassiana (Botanigard 22WP; Laverlam International Corp., Butte, MT) with the products rotated weekly. When spider mites (Tetranychus spp.) were detected on the foliage, abamectin (Avid 0.15EC; Syngenta Crop Protection, LLC, Greensboro, NC) was sprayed.

At the three- to four-leaf growth stage, $\approx 1$ month after planting, 25 of the most vigorous plants of each line were selected and each seedling transplanted into Sunshine Mix \#1 potting medium (SunGro Horticulture) in a D40 deepot (Stuewe and Sons, Inc., Tangent, OR). Ribs on the side of each deepot were removed and the deepots placed in a $35.6-\mathrm{cm} \times 35.6-\mathrm{cm}$ N25T rack (Stuewe and Sons, Inc.) with up to 25 deepots/rack. Granular imidacloprid (Marathon 1\% G; OHP, Inc., Mainland, PA) was applied to the potting soil in each deepot immediately after transplanting for insect control. Ten weeks after planting and $1 \mathrm{~d}$ before inoculation, each rack of 25 deepots was enclosed in a $0.05-\mathrm{mm}$ thick, $81.28-\mathrm{cm} \times 71.12-\mathrm{cm} \times$ $152.40-\mathrm{cm}$ plastic bag (U.S. Plastic Corp., Lima, $\mathrm{OH}$ ) and the bag closed to increase relative humidity and promote opening of stomata to facilitate infection by Xhc.

Isolate Car111 was grown on yeast dextrose calcium carbonate (YDC) agar medium (Schaad, 1988) at $\approx 20{ }^{\circ} \mathrm{C}$. The isolate was originally obtained from carrot seed in 2003 and demonstrated to be pathogenic on carrot (du Toit et al., 2005). Single bacterial colonies selected from YDC agar plates were each placed in $50 \mathrm{~mL}$ of 523 broth (Kado and Heskett, 1970) in each $125-\mathrm{mL}$ erlenmeyer flask. Inoculated flasks $(n=15)$ of 523 broth were placed on a shaker at $200 \mathrm{rpm}$ at $28{ }^{\circ} \mathrm{C}$ for $16 \mathrm{~h}$, after which the broth was pooled from all flasks into a $500-\mathrm{mL}$ flask. The bacterial suspension was adjusted to 0.10 optical density at $540 \mathrm{~nm}$ and the suspension diluted in $12.5 \mathrm{~mm} \mathrm{PO}_{4}$ buffer to obtain $5 \mathrm{~L}$ of inoculum at $10^{8} \mathrm{CFU} / \mathrm{mL}$. A $100-\mu \mathrm{L}$ aliquot of each dilution of a 10-fold dilution series prepared with a sample of the bacterial suspension was spread onto each of three plates of 523 agar medium/dilution to determine the inoculum concentration applied to the plants $\left(1.5 \times 10^{8}\right.$ to $\left.1.8 \times 10^{8} \mathrm{CFU} / \mathrm{mL}\right)$.

A pressurized Model $\mathrm{T}$ sprayer (Bellspray, Inc., Opelousas, LA) was used to inoculate the carrot foliage. The plastic bag covering each rack was removed, the plants sprayed until the foliage was visibly wet ( $\approx 58 \mathrm{~mL} / \mathrm{rack}$ ), and the plants enclosed again in the plastic bag. Approximately $72 \mathrm{~h}$ after inoculation, the bag was removed from each rack and the rack placed in a $40-\mathrm{cm} \times 40-\mathrm{cm} \times$ $12.7-\mathrm{cm}$ bin so that the plants could be watered by imbibition from the bottom of each deepot. Throughout the trial, $70 \%$ isopropanol was used to sanitize hands and tools after handling foliage of each line, and the plants in individual racks were staked and tied to minimize cross-contamination among lines. Three racks of non-inoculated plants of each of the two inbred lines were sprayed with $\mathrm{PO}_{4}$ buffer as control treatments but handled otherwise as done with the inoculated racks.

After inoculation, plants were monitored weekly for appearance of symptoms of bacterial blight. Visual ratings of bacterial blight symptoms were done for each line 4 and 5 weeks post-inoculation (wpi) based on the percentage foliage blighted for all 25 plants in a rack using a 0 to 10 scale, where: $0=0 \%$ foliage blighted and 1 to 10 represent $10 \%$ increments of total foliage with bacterial blight symptoms up to $100 \%$ blighting.

Approximately $6 \mathrm{wpi}$, individual plants were sampled and tested for the amount of $X h c$ on the foliage using a dilution plating method (du Toit et al., 2005). Foliage was cut separately from five of the 25 plants/line $\approx 1.5$ to $2.0 \mathrm{~cm}$ above the crown and rated for percentage bacterial blight symptoms. The foliage from each plant was then weighed and placed in a labeled paper bag. On the same day, the foliage of each plant was cut into pieces $\approx 5$ to $10 \mathrm{~mm}^{2}$ and the cut foliage placed in phosphate buffer $\left(12.5 \mathrm{mM} \mathrm{PO}_{4}\right)$ with the volume of buffer adjusted according to the amount of foliage sampled from each plant. The foliage and buffer were placed on a gyratory shaker at $250 \mathrm{rpm}$ for $1 \mathrm{~h}$.

A 10-fold dilution series was then prepared for each plant sampled. Depending on severity of the foliar rating for each plant, the dilution was carried out to $10^{-5}$ to $10^{-7}$ with greater dilutions for plants with more severe foliar blighting. The plates were maintained in the dark in incubators (Model I-30BLL and Model I-30VL; Percival Scientific, Perry, IA) set at $28^{\circ} \mathrm{C}$. The foliage in the buffer solution in each flask was then separated in a strainer, rolled in a paper towel, placed in a paper bag, and dried in an oven for 3 to $7 \mathrm{~d}$ to record foliar dry weight. After 3 to $5 \mathrm{~d}$, the XCS agar (du Toit et al., 2005; Williford and Schaad, 1984) plates for those dilutions that produced distinct colonies typical of $X h c$ were used to quantify $X h c$. Yellow, mucoid, raised colonies typical of this pathogen (du Toit et al., in press) were enumerated for each replicate of each dilution.

2013 trial. Seeds of the 46 carrot accessions listed in Tables 2 and 3 were planted into a $2.5-\mathrm{cm}$ layer of RediEarth Starter Medium on top of Sunshine Mix \#1 potting 


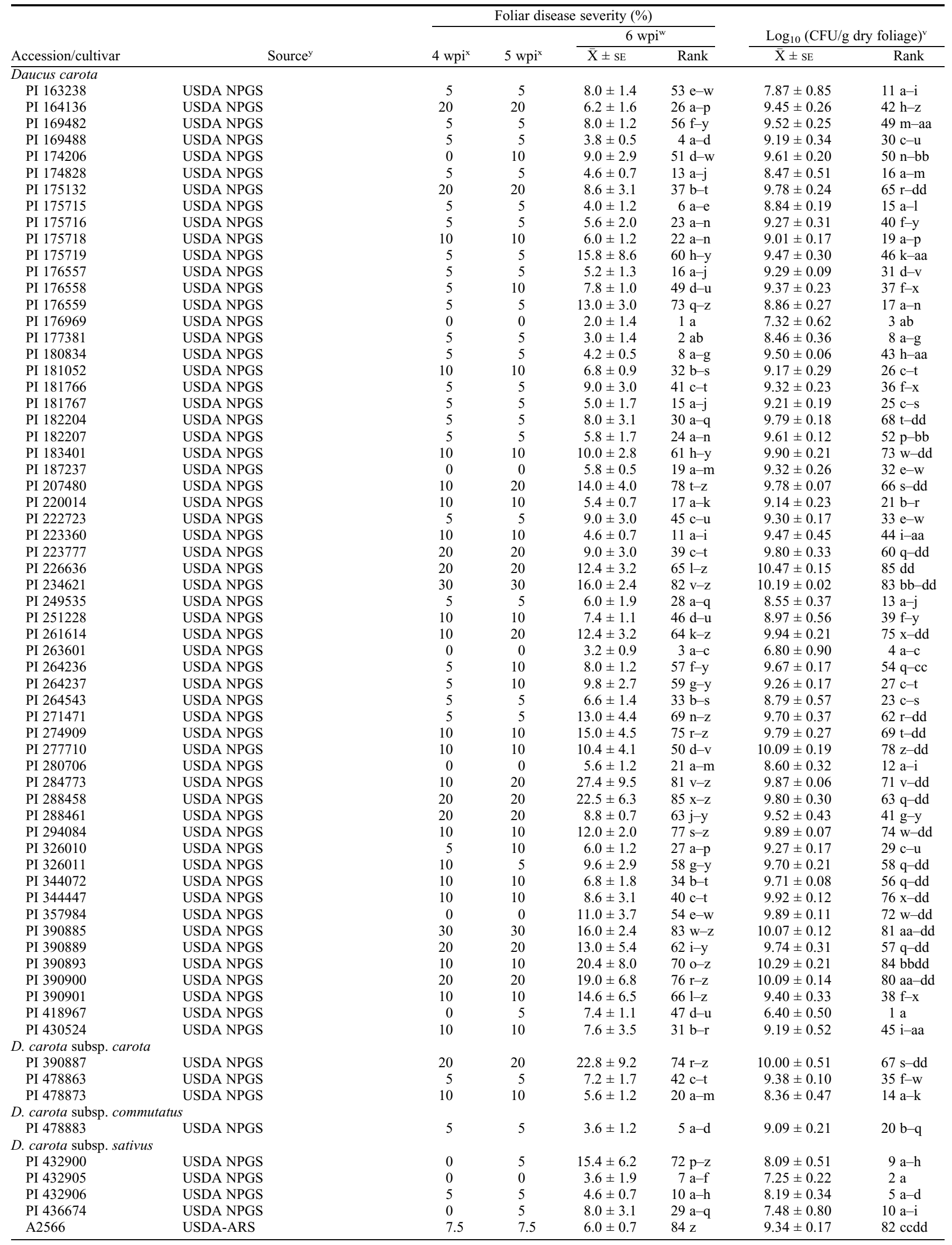


Table 1. (Continued) 2012 screening of carrot accessions for resistance to Xanthomonas hortorum pv. carotae. ${ }^{\mathrm{z}}$

\begin{tabular}{|c|c|c|c|c|c|c|c|}
\hline \multirow[b]{3}{*}{ Accession/cultivar } & \multirow[b]{3}{*}{ Source $^{y}$} & \multicolumn{4}{|c|}{ Foliar disease severity (\%) } & & \\
\hline & & \multirow[b]{2}{*}{$4 \mathrm{wpi}^{\mathrm{x}}$} & \multirow[b]{2}{*}{5 wpi $^{\mathrm{x}}$} & \multicolumn{2}{|c|}{$6 \mathrm{wpi}^{\mathrm{w}}$} & \multicolumn{2}{|c|}{$\log _{10}(\mathrm{CFU} / \mathrm{g} \text { dry foliage })^{\mathrm{v}}$} \\
\hline & & & & $\overline{\mathrm{X}} \pm \mathrm{SE}$ & Rank & $\overline{\mathrm{X}} \pm \mathrm{SE}$ & Rank \\
\hline $\mathrm{A} 0493$ & USDA-ARS & 5 & 5 & $4.8 \pm 1.0$ & $79 \mathrm{yz}$ & $8.87 \pm 0.16$ & 79 bbcc \\
\hline Nash's Nantes & Nash Huber & 15 & 20 & $19.0 \pm 4.0$ & $80 \mathrm{u}-\mathrm{Z}$ & $9.86 \pm 0.28$ & $70 \mathrm{u}-\mathrm{dd}$ \\
\hline Nash's Rumba & Nash Huber & 20 & 20 & $11.0 \pm 3.7$ & $52 \mathrm{e}-\mathrm{w}$ & $9.68 \pm 0.32$ & $53 \mathrm{q}-\mathrm{bb}$ \\
\hline $68017-1$ & Bejo Seeds & 5 & 5 & $11.0 \pm 2.4$ & $67 \mathrm{~m}-\mathrm{z}$ & $9.94 \pm 0.42$ & 59 q-dd \\
\hline Nelson & Bejo Seeds & 5 & 5 & $8.6 \pm 3.1$ & $43 \mathrm{c}-\mathrm{u}$ & $9.77 \pm 0.19$ & $61 \mathrm{r}-\mathrm{dd}$ \\
\hline Napa & Bejo Seeds & 5 & 5 & $4.4 \pm 1.2$ & $14 \mathrm{a}-\mathrm{j}$ & $9.17 \pm 0.21$ & $24 \mathrm{c}-\mathrm{s}$ \\
\hline Cupar & Bejo Seeds & 10 & 10 & $5.0 \pm 2.2$ & $18 \mathrm{a}-1$ & $7.44 \pm 0.76$ & $6 \mathrm{a}-\mathrm{e}$ \\
\hline Nerac & Bejo Seeds & 5 & 5 & $6.0 \pm 1.2$ & $25 \mathrm{a}-\mathrm{o}$ & $8.97 \pm 0.10$ & $18 \mathrm{a}-\mathrm{O}$ \\
\hline Nunhems 1-1 & Bayer CropScience Vegetable Seeds & 10 & 10 & $9.8 \pm 2.7$ & $55 \mathrm{e}-\mathrm{x}$ & $9.63 \pm 0.06$ & $51 \mathrm{o}-\mathrm{bb}$ \\
\hline Nunhems 1-2 & Bayer CropScience Vegetable Seeds & 0 & 5 & $4.6 \pm 0.7$ & $9 \mathrm{a}-\mathrm{h}$ & $8.39 \pm 0.29$ & $7 \mathrm{a}-\mathrm{f}$ \\
\hline Nunhems 1-3 & Bayer CropScience Vegetable Seeds & 5 & 10 & $7.0 \pm 1.4$ & $38 \mathrm{~b}-\mathrm{t}$ & $9.50 \pm 0.24$ & $47 \mathrm{k}-\mathrm{aa}$ \\
\hline Nunhems $1-4$ & Bayer CropScience Vegetable Seeds & 5 & 5 & $9.0 \pm 3.0$ & $48 \mathrm{~d}-\mathrm{u}$ & $9.15 \pm 0.40$ & $28 \mathrm{c}-\mathrm{u}$ \\
\hline Sugarsnax & Bayer CropScience Vegetable Seeds & 5 & 5 & $10.4 \pm 5.2$ & $44 \mathrm{c}-\mathrm{u}$ & $9.36 \pm 0.58$ & $481-\mathrm{aa}$ \\
\hline Tendersnax & Bayer CropScience Vegetable Seeds & 5 & 5 & $8.0 \pm 3.1$ & $35 \mathrm{~b}-\mathrm{t}$ & $9.76 \pm 0.31$ & $55 \mathrm{q}-\mathrm{dd}$ \\
\hline Enterprise & Monsanto Vegetable Seeds & 10 & 10 & $13.0 \pm 3.0$ & $71 \mathrm{p}-\mathrm{z}$ & $9.74 \pm 0.23$ & $64 \mathrm{r}-\mathrm{dd}$ \\
\hline Propeel & Monsanto Vegetable Seeds & 5 & 5 & $7.0 \pm 1.4$ & $36 \mathrm{~b}-\mathrm{t}$ & $9.94 \pm 0.14$ & $77 \mathrm{y}-\mathrm{dd}$ \\
\hline Triton & Sakata America & 5 & 5 & $4.6 \pm 0.7$ & $12 \mathrm{a}-\mathrm{i}$ & $9.17 \pm 0.19$ & $22 \mathrm{c}-\mathrm{r}$ \\
\hline Chantenay Red Core & Sakata America & 5 & 10 & $11.4 \pm 2.2$ & $68 \mathrm{~m}-\mathrm{Z}$ & $9.22 \pm 0.37$ & $34 \mathrm{e}-\mathrm{w}$ \\
\hline
\end{tabular}

${ }^{\mathrm{z}}$ Carrot plants $(\mathrm{n}=25 /$ line) were inoculated with $X$. hortorum pv. carotae in Nov. 2012, $63 \mathrm{~d}$ after planting.

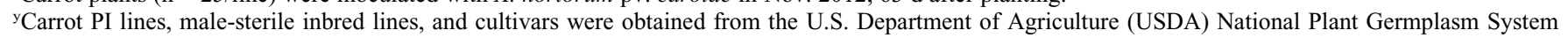

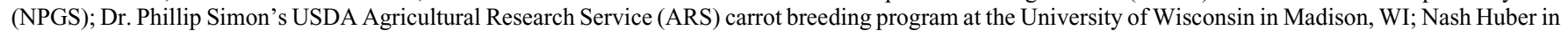
Sequim, WA; Bejo Seeds, Inc.; Bayer CropScience Vegetable Seeds; Monsanto Vegetable Seeds, Inc.; and Sakata America, Inc.

${ }^{\mathrm{x}}$ Mean percentage carrot foliage blighted 4 and 5 weeks post-inoculation (wpi).

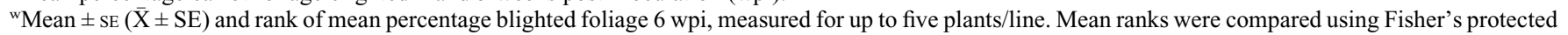
least significant difference (LSD) at $P \leq 0.05$; ranks with at least one letter in common were not significantly different.

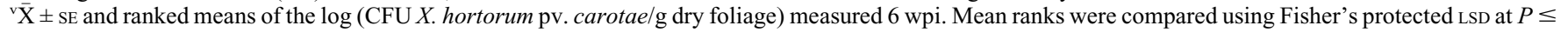
0.05 ; ranks with at least one letter in common were not significantly different.

$\mathrm{CFU}=$ colony-forming units.

Table 2. Accession, species, and source of carrot wild relatives and cultivars evaluated in a 2013 greenhouse screening for resistance to Xanthomonas hortorum pv. carotae.

\begin{tabular}{|c|c|c|}
\hline Accession/cultivar & Species & Source $^{z}$ \\
\hline Ames 30198 & Daucus capillifolius & USDA NPGS \\
\hline Ames 30214 & D. capillifolius & USDA NPGS \\
\hline SS109 CA & D. carota & USDA-ARS \\
\hline RDC 5 WI & D. carota & USDA-ARS \\
\hline SS10 OR & D. carota & USDA-ARS \\
\hline Ames 7674 & D. carota subsp. commutatus & USDA NPGS \\
\hline PI 652291 & D. carota subsp. commutatus & USDA NPGS \\
\hline Ames 26381 & D. carota subsp. fontanesii & USDA NPGS \\
\hline Ames 31193 & D. carota subsp. gadecaei & USDA NPGS \\
\hline Ames 26382 & D. carota subsp. gummifer & USDA NPGS \\
\hline Ames 26383 & D. carota subsp. gummifer & USDA NPGS \\
\hline Ames 26384 & D. carota subsp. gummifer & USDA NPGS \\
\hline CEC1 WA & Daucus sp. & Charles E. Christianson \\
\hline Nunhems 2-1 & D. carota subsp. sativus & Bayer CropScience Vegetable Seeds \\
\hline Nunhems 2-2 & D. carota subsp. sativus & Bayer CropScience Vegetable Seeds \\
\hline Nunhems 2-3 & D. carota subsp. sativus & Bayer CropScience Vegetable Seeds \\
\hline Nunhems 2-4 & D. carota subsp. sativus & Bayer CropScience Vegetable Seeds \\
\hline \multicolumn{3}{|c|}{$\begin{array}{l}\text { zSeed supplied by the U.S. Department of Agriculture (USDA) National Plant Germplasm System } \\
\text { (NPGS); Dr. Phillip Simon's USDA Agricultural Research Service (ARS) program at the University of } \\
\text { Wisconsin in Madison, WI; Charles Christianson in Bay View, WA (lat. } 48.479931^{\circ} \text { N, long. } 122.473065^{\circ} \\
\text { W) from a wild carrot plant that set seed; and Bayer CropScience Vegetable Seeds. }\end{array}$} \\
\hline
\end{tabular}

mix in D40H deepots in the 2013 greenhouse trial. The accessions included 12 carrot wild relatives from the collection of Dr. Philip Simon with the USDA-ARS; one wild carrot collected in Bay View, WA, by Charles E. Christianson; four cultivars (one developed for resistance to $X h c$ and three selected for susceptibility to $X h c$ ) from Bayer Cropscience Vegetable Seeds; 13 PI lines selected from the 2012 trial (eight partially resistant and five highly susceptible to $X h c$ based on the $X h c$ population size detected as well as foliar severity rating $6 \mathrm{wpi}$ ); two PI lines that had abnormal foliar growth in the 2012 trial that impeded adequate assessment of reaction to inoculation with Xhc (PI 187237 and 357984); eight commercial (openpollinated and hybrid) cultivars from the 2012 trial; an additional four proprietary cultivars from Bayer CropScience Vegetable Seeds selected for resistance (one line) or susceptibility (three lines) to bacterial blight; and the two inbred lines evaluated in 2012 . Two seeds were planted/pot and the seedlings thinned to one plant/pot 2 weeks after planting. After 4 weeks, the deepots were randomized into five complete blocks with five plants (subsamples)/block. Plants were grown in the same manner as the 2012 trial. Nutritional deficiency symptoms were observed on the foliage of some lines 4 weeks after planting. Analysis of the potting medium by Soiltest Farm Consultants, Inc. (Moses Lake, WA) revealed the medium was deficient in boron (B) and copper $(\mathrm{Cu})$. Therefore, a foliar application of B (NUE Boron 4\%; BioGro, Inc., Mabton, WA) was made 6 weeks after planting, and daily fertigated applications of $\mathrm{Cu}$ (Cop-Plex; Northwest Agricultural Products, LLC, Pasco, WA) were carried out.

The same inoculation protocol used in the 2012 trial was followed in the 2013 trial, except that $89.3 \mathrm{~mL}$ of $X h c$ suspension at $10^{8} \mathrm{CFU} / \mathrm{mL}$ was applied to each set of 25 plants/line (five replicates of five plants), and the plants in each rack were enclosed in a $0.03-\mathrm{mm}$ thick, $96-\mathrm{cm} \times 130-\mathrm{cm}$ plastic bag (HDX; Home Depot, Atlanta, GA). $\mathrm{PO}_{4}$ buffer was applied to 25 plants of each of the male-sterile inbred lines (five replicates of five plants/line) as non-inoculated control treatments, like in 2012. The percentage carrot foliage blighted was recorded 3 and 4 wpi for each set of five plants/replication/ line. The foliage of each plant was cut 6 wpi as described for the 2012 trial. Some plants had senesced before sampling, resulting in less than 25 plants sampled for those lines. The cut foliage was harvested, washed, and a dilution series plated like in the 2012 trial.

Data analysis. The 2012 and 2013 data were analyzed using SAS Version 9.2 (SAS Institute, Cary, NC). The size of the Xhc population recovered/plant (CFU/g dry foliage) was calculated based on $\mathrm{CFU} / \mathrm{mL}$ buffer for the dilution that resulted in quantifiable bacterial populations. Data for CFU/g 
Table 3. 2013 greenhouse screening of carrot accessions and cultivars for resistance to Xanthomonas hortorum pv. carotae: mean disease severity rated 3, 4, and 6 weeks post-inoculation (wpi), means comparison of ranked disease severity ratings $6 \mathrm{wpi}$, and population of the pathogen detected on the foliage 6 wpi. $^{2}$

\begin{tabular}{|c|c|c|c|c|c|c|c|}
\hline \multirow[b]{2}{*}{ Accession/cultivar } & \multirow[b]{2}{*}{$\mathrm{N}$} & \multirow{2}{*}{$\begin{array}{l}3 \text { wpi }^{y} \\
\text { Mean }\end{array}$} & \multirow{2}{*}{$\begin{array}{l}4 \text { wpi }^{y} \\
\text { Mean }\end{array}$} & \multicolumn{2}{|c|}{$6 \mathrm{wpi}^{\mathrm{x}}$} & \multicolumn{2}{|c|}{$\log _{10}(\mathrm{CFU} / \mathrm{g}$ dry foliage $)$} \\
\hline & & & & $\overline{\text { Mean } \pm \text { SE }}$ & Rank & Mean $\pm \mathrm{SE}^{\mathrm{w}}$ & Rank $^{v}$ \\
\hline PI 163238 & 23 & 3.0 & 5.6 & $7.6 \pm 1.8$ & $15 \mathrm{e}-\mathrm{k}$ & $8.00 \pm 0.33$ & $10 \mathrm{~d}-\mathrm{f}$ \\
\hline PI 176969 & 21 & 4.0 & 7.2 & $4.3 \pm 0.9$ & $6 \mathrm{c}-\mathrm{e}$ & $9.18 \pm 0.17$ & $15 \mathrm{~h}-\mathrm{k}$ \\
\hline PI 177381 & 23 & 3.8 & 6.0 & $5.2 \pm 0.9$ & $10 \mathrm{~d}-\mathrm{g}$ & $9.31 \pm 0.21$ & $20 \mathrm{j}-\mathrm{m}$ \\
\hline PI 187237 & 23 & 2.2 & 5.6 & $6.2 \pm 1.6$ & $13 \mathrm{e}-\mathrm{i}$ & $8.91 \pm 0.31$ & $14 \mathrm{~h}-\mathrm{j}$ \\
\hline PI 226636 & 24 & 6.2 & 10.4 & $7.6 \pm 1.2$ & $17 \mathrm{~g}-1$ & $9.53 \pm 0.11$ & $30 j-n$ \\
\hline PI 234621 & 25 & 8.6 & 14.0 & $22.5 \pm 3.0$ & $39 \mathrm{st}$ & $9.62 \pm 0.07$ & $24 \mathrm{k}-\mathrm{q}$ \\
\hline PI 263601 & 25 & 1.6 & 5.0 & $5.8 \pm 1.3$ & $11 \mathrm{~d}-\mathrm{h}$ & $7.61 \pm 0.19$ & $5 b-d$ \\
\hline PI 277710 & 23 & 6.0 & 7.6 & $8.2 \pm 1.9$ & $16 \mathrm{f}-1$ & $9.06 \pm 0.30$ & $18 \mathrm{i}-1$ \\
\hline PI 357984 & 23 & 4.6 & 6.4 & $11.8 \pm 1.6$ & 29 o-q & $9.73 \pm 0.08$ & $27 \mathrm{~m}-\mathrm{r}$ \\
\hline PI 390893 & 23 & 13.0 & 19.0 & $34.4 \pm 4.0$ & $41 \mathrm{u}$ & $10.00 \pm 0.14$ & $36 \mathrm{~s}-\mathrm{w}$ \\
\hline PI 418967 & 24 & 0.0 & 1.2 & $1.8 \pm 0.4$ & $2 \mathrm{ab}$ & $6.25 \pm 0.16$ & $1 \mathrm{a}$ \\
\hline PI 390887 & 24 & 19.0 & 25.0 & $44.8 \pm 4.2$ & $42 \mathrm{u}$ & $9.48 \pm 0.17$ & $23 \mathrm{k}-\mathrm{p}$ \\
\hline PI 432905 & 25 & 2.4 & 5.0 & $6.1 \pm 2.0$ & $8 \mathrm{de}$ & $7.16 \pm 0.19$ & $3 a-c$ \\
\hline PI 432906 & 25 & 1.8 & 4.6 & $1.9 \pm 0.4$ & $3 a-c$ & $7.16 \pm 0.21$ & $4 a-c$ \\
\hline PI 436674 & 24 & 1.8 & 4.2 & $7.2 \pm 2.3$ & $12 \mathrm{~d}-\mathrm{i}$ & $8.17 \pm 0.21$ & $8 \mathrm{de}$ \\
\hline A2566 & 25 & 6.0 & 10.4 & $13.0 \pm 2.0$ & $30 o-q$ & $9.91 \pm 0.08$ & $32 \mathrm{q}-\mathrm{s}$ \\
\hline A0493 & 25 & 3.4 & 4.6 & $10.4 \pm 1.3$ & $27 \mathrm{~m}-\mathrm{p}$ & $9.87 \pm 0.11$ & $300-s$ \\
\hline Nash's Nantes & 25 & 2.4 & 4.6 & $8.5 \pm 1.0$ & $22 \mathrm{k}-\mathrm{O}$ & $9.72 \pm 0.16$ & $28 \mathrm{~m}-\mathrm{s}$ \\
\hline Nash's Rumba & 23 & 7.2 & 10.0 & $19.5 \pm 3.0$ & $36 \mathrm{rs}$ & $9.81 \pm 0.13$ & $31 \mathrm{p}-\mathrm{s}$ \\
\hline 68017-1 Вејо & 25 & 3.2 & 6.4 & $9.1 \pm 1.1$ & $231-0$ & $9.65 \pm 0.10$ & $251-r$ \\
\hline Cupar & 24 & 3.4 & 5.4 & $8.6 \pm 1.6$ & $20 \mathrm{j}-\mathrm{n}$ & $8.28 \pm 0.28$ & $11 \mathrm{e}-\mathrm{g}$ \\
\hline Nunhems 1-2 & 24 & 3.4 & 4.2 & $7.5 \pm 1.0$ & $19 \mathrm{i}-\mathrm{m}$ & $9.35 \pm 0.09$ & $17 \mathrm{~h}-\mathrm{k}$ \\
\hline Nunhems 1-3 & 25 & 3.4 & 8.2 & $17.4 \pm 1.9$ & $35 \mathrm{rs}$ & $10.26 \pm 0.06$ & $41 \times$ \\
\hline Tendersnax & 25 & 3.6 & 6.2 & $14.3 \pm 1.8$ & $32 \mathrm{p}-\mathrm{s}$ & $10.26 \pm 0.06$ & 40 wx \\
\hline Triton & 25 & 4.6 & 8.4 & $15.2 \pm 1.5$ & $34 \mathrm{q}-\mathrm{s}$ & $9.91 \pm 0.08$ & $33 r-t$ \\
\hline Ames 30198 & 22 & 2.4 & 5.2 & $7.8 \pm 1.1$ & $18 \mathrm{~h}-\mathrm{m}$ & $9.81 \pm 0.22$ & $35 \mathrm{r}-\mathrm{v}$ \\
\hline Ames 30214 & 11 & 8.3 & 10.0 & $22.8 \pm 5.0$ & $33 \mathrm{p}-\mathrm{s}$ & $9.55 \pm 0.32$ & $26 \mathrm{k}-\mathrm{s}$ \\
\hline SS109 CA & 19 & 5.8 & 9.0 & $5.5 \pm 0.7$ & $14 \mathrm{~d}-\mathrm{j}$ & $9.72 \pm 0.21$ & $29 n-s$ \\
\hline RDC 5 WI & 6 & 6.5 & 7.5 & $15.8 \pm 5.7$ & $25 \mathrm{k}-\mathrm{r}$ & $9.4 \pm 0.37$ & $19 \mathrm{~g}-\mathrm{O}$ \\
\hline SS10 OR & 10 & 2.7 & 3.7 & $5.7 \pm 1.6$ & $7 b-f$ & $8.16 \pm 0.46$ & $9 \mathrm{c}-\mathrm{f}$ \\
\hline Ames 7674 & 13 & 2.3 & 3.0 & $4.8 \pm 0.9$ & $5 \mathrm{~b}-\mathrm{e}$ & $8.21 \pm 0.23$ & $6 \mathrm{~b}-\mathrm{e}$ \\
\hline PI 652291 & 23 & 5.0 & 7.0 & $11.9 \pm 1.5$ & $28 \mathrm{n}-\mathrm{p}$ & $9.59 \pm 0.11$ & $22 \mathrm{k}-\mathrm{p}$ \\
\hline Ames 26381 & 25 & 5.2 & 7.2 & $19.1 \pm 3.4$ & $31 \mathrm{p}-\mathrm{s}$ & $10.14 \pm 0.16$ & $37 t-x$ \\
\hline Ames 31193 & 25 & 2.6 & 3.8 & $5.0 \pm 0.7$ & $9 d-g$ & $8.86 \pm 0.19$ & $13 \mathrm{f}-\mathrm{i}$ \\
\hline Ames 26382 & 25 & 3.4 & 4.6 & $9.2 \pm 1.5$ & $21 \mathrm{k}-\mathrm{n}$ & $8.80 \pm 0.19$ & $12 \mathrm{f}-\mathrm{h}$ \\
\hline Ames 26383 & 25 & 5.4 & 6.6 & $10.8 \pm 1.7$ & $241-0$ & $9.10 \pm 0.19$ & $16 \mathrm{~h}-\mathrm{k}$ \\
\hline Ames 26384 & 22 & 8.4 & 11.0 & $11.8 \pm 2.0$ & $26 \mathrm{~m}-\mathrm{p}$ & $9.84 \pm 0.17$ & $34 \mathrm{r}-\mathrm{u}$ \\
\hline CEC1 WA & 24 & 1.2 & 3.2 & $3.4 \pm 0.4$ & $4 b-d$ & $8.17 \pm 0.17$ & $7 \mathrm{c}-\mathrm{e}$ \\
\hline Nunhems 2-1 & 25 & 0.0 & 0.4 & $0.4 \pm 0.2$ & $1 \mathrm{a}$ & $6.87 \pm 0.12$ & $2 a b$ \\
\hline Nunhems 2-2 & 25 & 9.4 & 14.0 & $24.8 \pm 1.5$ & $40 \mathrm{tu}$ & $10.41 \pm 0.07$ & $42 \mathrm{x}$ \\
\hline Nunhems 2-3 & 25 & 6.2 & 8.8 & $17.2 \pm 1.5$ & $38 \mathrm{st}$ & $10.21 \pm 0.09$ & $39 v-x$ \\
\hline Nunhems 2-4 & 25 & 9.8 & 12.4 & $19.0 \pm 2.2$ & $37 \mathrm{~s}$ & $10.15 \pm 0.14$ & $38 \mathrm{u}-\mathrm{x}$ \\
\hline
\end{tabular}

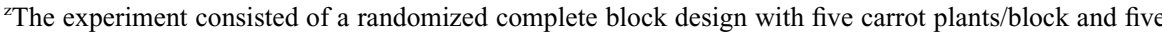
replicate blocks/line. Plants were inoculated with $X$. hortorum pv. carotae in July 2013, $65 \mathrm{~d}$ after planting, and the foliage tested to quantify the pathogen $6 \mathrm{wpi}$, as described in the main text.

${ }^{y}$ Mean percentage carrot foliage blighted 3 and 4 wpi for 25 carrot plants/line or less.

${ }^{\mathrm{x}}$ Mean $\pm \mathrm{SE}$ and rank of percentage carrot foliage blighted 6 wpi for five carrot plants assayed/replication/ line. Ranks of the severity ratings were compared using Fisher's protected least significant difference (LSD) at $P \leq 0.05$; lines with means separation letters in common did not differ significantly.

${ }^{\mathrm{w}}$ Mean $\pm \mathrm{SE}$ of $X$. hortorum pv. carotae population detected on the foliage 6 wpi for up to five plants/ replication.

${ }^{v}$ Mean rank in $X$. hortorum pv. carotae population detected on the foliage 6 wpi for five plants/replication. Ranks for each line were compared using Fisher's protected least significant difference (LSD at $P \leq 0.05$ ). Lines with means separation letters in common did not differ significantly.

$\mathrm{CFU}=$ colony-forming units.

dry foliage were log-transformed $\left[\mathrm{y}=\log _{10}\right.$ (CFU/g dry foliage)]. Carrot lines were treated as a fixed effect and replications as a random effect in the analysis of variance. The log-transformed data for all lines and cultivars tested in each of 2012 and 2013 did not meet the assumptions of normally distributed residuals and homogeneous variances for parametric analysis. Other transformations also did not satisfy these assumptions. Friedman's non-parametric rank test and Fisher's protected least significant difference $(P<$ $0.05)$ were carried out on ranked pathogen

\section{Results}

2012 trial. Bacterial blight symptoms were observed on at least one, and typically all, inoculated plants of each accession evaluated in the 2012 trial, demonstrating success of the inoculation protocol for establishing the disease. No symptoms were observed on plants of the non-inoculated inbred lines 4 and 5 wpi. By 6 wpi, all but one noninoculated plant had $0 \%$ foliage blighted; the remaining plant had 3\% blighting compared with an average $8.8 \%$ blighting for all inoculated plants. Symptoms typically began as chlorotic lesions that developed into angular, water-soaked lesions and eventually brown or black, necrotic lesions. However, there were variations in symptoms among entries including purple discoloration along the leaf margins and purple symptoms that turned necrotic (e.g., PI 226636 and 288458). Disease severity varied extensively among accessions at each of the weekly ratings (Table 1; Fig. 1A).

Severity of foliar blighting ranged from $0 \%$ to $30 \%$ for individual entries at both 4 and 5 wpi with a mean \pm SE of foliar rating for all 85 lines of $8.0 \% \pm 0.7 \%$ and $9.1 \% \pm 0.7 \%$, respectively (Table 1). By 6 wpi, disease ratings on individual plants ranged from $0 \%$ to $50 \%$ and averaged $8.8 \% \pm 0.4 \%$ for all lines tested with the PI lines averaging 9.3\% foliage-blighted, the 17 cultivars averaging $8.8 \%$, and the two inbred lines $5.4 \%$. Spearman's correlation coefficients for disease ratings 4,5 , and 6 wpi were highly significant for all 85 entries $(r=0.44$ to 0.89 at $P<$ 0.0001 for all pairs of ratings) (Table 4). Similarly, correlation coefficients for foliar disease ratings 4,5 , and 6 wpi were significant for all 66 PI lines and for the 17 cultivars (Table 4). Friedman's rank test showed a significant effect of carrot line on the population size of $X h c$ recovered from the foliage $\left(P<0.0001\right.$ for $\log _{10} \mathrm{CFU} / \mathrm{g}$ dry foliage) as well as severity of symptoms 6 wpi $(P<0.0001)$.

Bacterial populations recovered from the foliage of inoculated plants ranged from $\log _{10}$ 4.14 to $\log _{10} 11.52 \mathrm{CFU} / \mathrm{g}$ dry foliage with a mean of $\log _{10} 9.23 \pm 0.05 \mathrm{CFU} / \mathrm{g}$ dry foliage (Table 1). Bacterial blight symptoms did not appear until $X h c$ populations were greater than $\log _{10} 6.00 \mathrm{CFU} / \mathrm{g}$ dry foliage and, as symptoms became more severe, the bacterial population increased at a diminishing rate (Fig. 1A). However, Spearman's correlation coefficients for Xhc population size vs. foliar disease ratings 4,5 , and 6 wpi were highly significant $(P<0.0001)$ when calculated for all 85 entries (Table 4). The interquartile range (middle $50 \%$ of data) of all plants tested had Xhc populations of $\log _{10} 8.83$ to $\log _{10} 9.87 \mathrm{CFU} / \mathrm{g}$ dry foliage (Fig. 2A) as a gauge of potential genetic variability within groups of lines and cultivars. The pathogen was not detected on eight of the 15 noninoculated inbred plants. Three control plants had $\log _{10} 4.000 \mathrm{CFU} / \mathrm{g}$ or less dry foliage, and other four had $\log _{10} 5.084$ to $\log _{10}$ $7.799 \mathrm{CFU} / \mathrm{g}$ dry foliage, demonstrating 

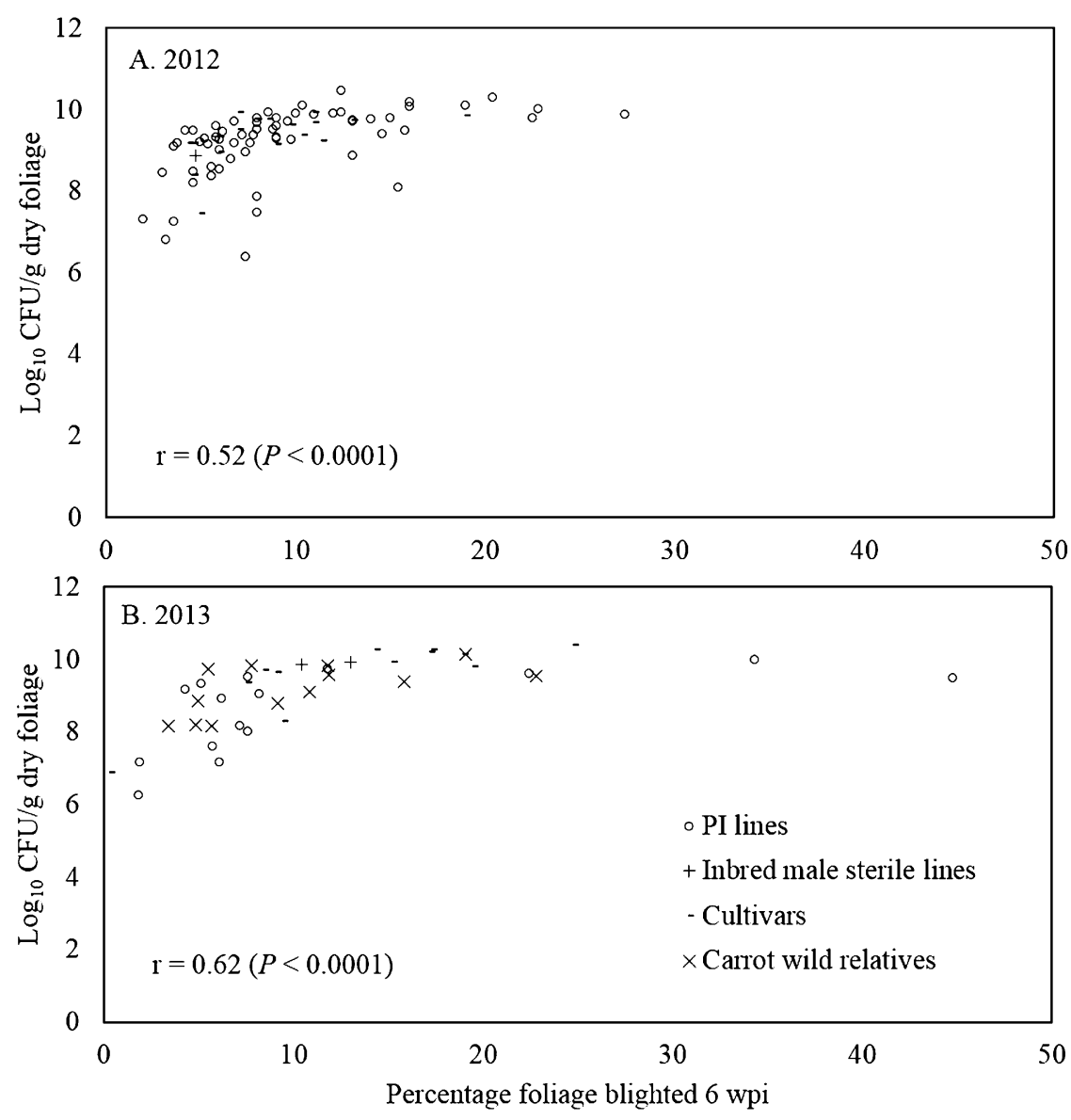

Fig. 1. (A) Xanthomonas hortorum pv. carotae population recovered on a semiselective agar medium vs. bacterial blight severity on carrot foliage 6 weeks post-inoculation (wpi) in a 2012 greenhouse screening of 66 PI lines, two inbred male-sterile carrot lines (A2566 and A0493), and 17 carrot cultivars. $r=$ Spearman's correlation coefficient (and associated probability, $P$ ). (B) X. hortorum pv. carotae population vs. bacterial blight severity on carrot foliage measured 6 wpi from a 2013 greenhouse screening of 15 PI lines, the same two inbred male-sterile carrot lines, eight cultivars, and 13 carrot wild relatives.

Table 4. Spearman's correlation coefficient, $r$, between ratings of bacterial blight severity measured 4, 5, and 6 weeks post-inoculation (wpi) and between disease ratings and population size of Xanthomonas hortorum pv. carotae quantified on carrot foliage 6 wpi in a 2012 greenhouse screening of 66 carrot PI lines, 17 cultivars, and two inbred male-sterile lines.

\begin{tabular}{|c|c|c|c|c|}
\hline \multirow[b]{2}{*}{ Carrot entries } & \multirow{2}{*}{$\begin{array}{l}\text { Foliar disease } \\
\text { severity rating }\end{array}$} & \multicolumn{2}{|c|}{ Foliar disease severity rating } & \multirow{2}{*}{$\begin{array}{c}\log _{10}(\mathrm{CFU} X \text {. hortorum pv. } \\
\text { carotae/g dry foliage })^{\mathrm{y}}\end{array}$} \\
\hline & & $5 \mathrm{wpi}^{\mathrm{z}}$ & $6 \mathrm{wpi}^{\mathrm{z}}$ & \\
\hline \multirow[t]{3}{*}{ All entries ${ }^{x}$} & 4 wpi & $0.89 * * * u$ & $0.44 * * *$ & $0.54 * * *$ \\
\hline & 5 wpi & - & $0.50 * * *$ & $0.50 * * *$ \\
\hline & $6 \mathrm{wpi}$ & - & - & $0.52 * * *$ \\
\hline \multirow[t]{3}{*}{ PI linesw } & 4 wpi & $0.87 * * *$ & $0.42 * * *$ & $0.62 * * *$ \\
\hline & 5 wpi & - & $0.45 * * *$ & $0.60 * * *$ \\
\hline & 6 wpi & - & - & $0.53 * * *$ \\
\hline \multirow[t]{3}{*}{ Cultivars $^{\mathrm{v}}$} & 4 wpi & $0.81 * * *$ & $0.59 *$ & $0.20 \mathrm{NS}$ \\
\hline & 5 wpi & - & $0.69 * *$ & $0.19 \mathrm{NS}$ \\
\hline & $6 \mathrm{wpi}$ & - & - & $0.56 * * *$ \\
\hline
\end{tabular}

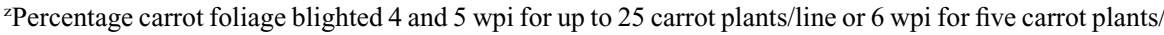
line after the carrot foliage was inoculated with $X$. hortorum pv. carotae.

${ }^{\mathrm{y}}$ Mean $X$. hortorum pv. carotae population detected on carrot foliage 6 wpi for five carrot plants/line.

${ }^{\mathrm{x}} \mathrm{N}=91$ plants rated for percentage of foliage blighted 4 and $5 \mathrm{wpi} ; \mathrm{N}=454$ plants evaluated for percentage foliage blighted and $X$. hortorum pv. carotae population detected on carrot foliage 6 wpi.

${ }^{\mathrm{w}} \mathrm{N}=66$ plants rated for percentage foliage blighted 4 and $5 \mathrm{wpi} ; \mathrm{N}=329$ plants evaluated for percentage foliage blighted and $X$. hortorum pv. carotae population detected on carrot foliage 6 wpi.

${ }^{\mathrm{v}} \mathrm{N}=17$ plants rated for percentage foliage blighted 4 and $5 \mathrm{wpi} ; \mathrm{N}=85$ plants evaluated for percentage foliage blighted and $X$. hortorum pv. carotae population detected on carrot foliage 6 wpi.

${ }^{\mathrm{u}} \mathrm{NS}=$ nonsignificant at $P \leq 0.05 ; *{ }^{* *}$, and ***significant at $P \leq 0.05,0.01$, and 0.001 , respectively.

$\mathrm{CFU}=$ colony-forming units.

potential cross-contamination among plants and/or transmission from infested seed of these inbred lines. $r=0.62,0.60$, and 0.53 , respectively (Table 4). In contrast, Spearman's correlation coefficients of $X h c$ population size vs. disease ratings were not significant for the 17 cultivars 4 and 5 wpi but was highly significant by 6 wpi with $r=0.56(P<0.0001)$ (Table $4)$. Correlation coefficients of pathogen population size vs. foliar disease ratings were not significant for the two inbred lines. Several PI lines were outliers because of limited mean bacterial population sizes detected on the foliage despite relatively severe foliar disease ratings, i.e., PI 163238 , 418967, 432900, and 436674 with mean foliar ratings of $8.0 \%, 7.4 \%, 15.4 \%$, and $8.0 \%$ blighting, respectively, compared with mean pathogen population sizes of $\log _{10} 7.87, \log _{10} 6.40, \log _{10}$ 8.09, and $\log _{10} 7.48 \mathrm{CFU} / \mathrm{g}$ dry foliage, respectively (Table 1; Fig. 1A).

Foliar symptoms were not observed on any plants of PI 176969 at 4 and 5 wpi. This PI line had the least severe foliar blight $6 \mathrm{wpi}$ and ranked the third least in bacterial population recovered from the foliage $\left(\log _{10}\right.$ $7.319 \pm 0.621 \mathrm{CFU} / \mathrm{g}$ dry foliage), which was similar statistically to that of 20 other PI lines and cultivars (Table 1). PI 418967 had the least $X$ hc recovered from foliage ( $\log _{10}$ $6.398 \pm 0.498 \mathrm{CFU} / \mathrm{g}$ dry foliage) and ranked 47 of the 85 entries for foliar disease severity 6 wpi (Table 1). In contrast, PI 284773 had the greatest average disease severity $6 \mathrm{wpi}$ (27.4\% foliage-blighted) and ranked 71 of 85 for mean population size of Xhc detected $\left(\log _{10} 9.872 \pm 0.060 \mathrm{CFU} / \mathrm{g}\right.$ dry foliage) (Table 1). PI 226636 had the greatest population of Xhc of all the entries $\left(\log _{10} 10.465 \pm\right.$ $0.152 \mathrm{CFU} / \mathrm{g}$ dry foliage) and ranked 82 of the 85 accessions for severity of bacterial blight 6 wpi (12.4\%) (Table 1).

2013 trial. Bacterial blight symptoms were observed 6 wpi on at least one, and typically all, inoculated plants of all 42 carrot accessions evaluated in the 2013 trial. Bacterial blight was not observed on two plants of each of PI 418967 and Nunhems 2-1 at 3 and 4 wpi. By 6 wpi, three of the 25 noninoculated plants of each of A2566 and A0493 had 3\% foliage-blighted, whereas the remaining 22 control plants of each line were asymptomatic. Like in the 2012 trial, severity of foliar symptoms varied among entries (Table 3; Fig. 1B). Additionally, slightly different symptoms were observed for some accessions compared with 2012. In particular, lesions on plants of the carrot wild relative Ames 26384 were chlorotic, did not develop water-soaking, and had relatively distinct margins, unlike lesions on most other entries.

Disease severity measured 3, 4, and 6 wpi varied among all accessions evaluated in 2013 (Table 3; Fig. 1B). For all 42 accessions, foliar disease ratings $2,3,4$, and $6 \mathrm{wpi}$ averaged $1.9 \% \pm 0.1 \%$ (range, $0 \%$ to $10 \%$ ), $4.8 \% \pm 0.3 \%(0 \%$ to $20 \%), 7.5 \% \pm 0.4 \%(0 \%$ to $30 \%)$, and $11.8 \% \pm 0.4 \%(0 \%$ to $90 \%)$. The eight putatively resistant PI lines selected from the 2012 trial averaged severity ratings of $0.6 \pm 0.2,2.3 \pm 0.3,4.9 \pm 0.4$, and $5.0 \pm$
$X$ hc population sizes were highly significantly correlated $(P<0.0001)$ with disease ratings 4,5 , and 6 wpi for the 66 PIs with 

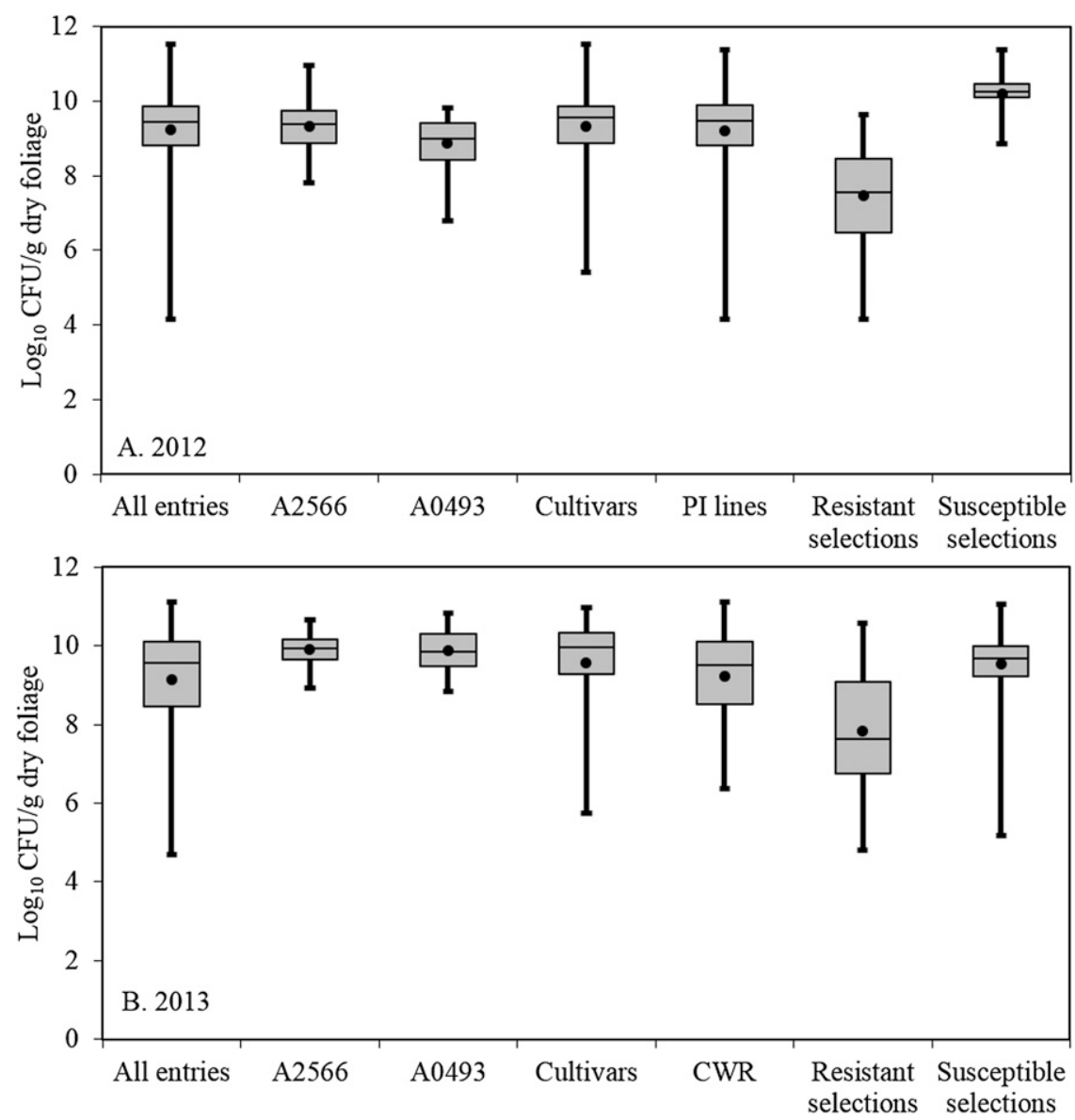

Fig. 2. (A) Population of Xanthomonas hortorum pv. carotae detected on the foliage of 85 carro accessions and cultivars tested, including two inbred male-sterile carrot lines (A2566 and A0493), 17 cultivars, 66 PI lines, eight resistant selections, and five susceptible selections from a 2012 greenhouse screening; and (B) of 42 accessions and cultivars tested in a 2013 greenhouse screening, including the same two inbred male-sterile lines, eight cultivars, and 13 carrot wild relatives (CWR) as well as eight partially resistant PI lines and five highly susceptible PI lines selected from the 2012 screening. The black dot for each group of entries represents the mean, the horizontal line in each box represents the median, the upper and lower ends of each box represent the first and third quartiles, respectively, and the whiskers represent the range in pathogen population size detected.

$0.5 \%$ at $2,3,4$, and 6 wpi, respectively, whereas the five putative susceptible PI lines selected averaged foliar ratings of $4.0 \% \pm$ $0.6 \%, 10.4 \% \pm 1.2 \%, 15.0 \% \pm 1.5 \%$, and $23.4 \% \pm 1.9 \%$, respectively (Table 3 ). In comparison, the 12 commercial cultivars averaged $1.8 \% \pm 0.2 \%, 4.7 \% \pm 0.4 \%, 7.4 \%$ $\pm 0.6 \%$, and $13.5 \% \pm 0.6 \%$ bacterial blight severity at 2, 3, 4, and 6 wpi, respectively; the 12 carrot wild relatives averaged $2.0 \% \pm$ $0.2 \%, 4.5 \% \pm 0.4 \%, 6.3 \% \pm 0.5 \%$, and $9.8 \% \pm 0.6 \%$, respectively; and the two inbred lines averaged $2.4 \% \pm 0.4 \%, 4.7 \% \pm$ $0.7 \%, 7.5 \% \pm 1.2 \%$, and $11.7 \% \pm 1.2 \%$, respectively. PI 187237 and 357984 , the two PI lines screened again in 2013 because of abnormal growth impeding adequate evaluations in 2012, averaged foliar blight severities at 6 wpi of $6.2 \% \pm 1.6 \%$ and $11.8 \% \pm 1.6 \%$, respectively, which ranked 13 and 29 of the 42 entries, respectively (Table 3). CEC1 WA, the wild carrot plant collected by Charles E. Christianson, averaged $3.4 \% \pm 0.4 \%$ foliar blighting by $6 \mathrm{wpi}$, which ranked fourth out of the 42 entries (Table 2).
Spearman's correlation coefficients of disease ratings 3,4 , and 6 wpi were highly significant $(P<0.0001)$ for all entries tested in 2013 ( $r=0.53$ to 0.82$)$ (Table 5). Likewise, correlation coefficients of foliar disease ratings 3,4 , and 6 wpi were highly significant when calculated separately for the $15 \mathrm{PI}$ lines, 12 cultivars, and 12 carrot wild relatives (Table 5). Friedman's rank test of $\log _{10}$ $\mathrm{CFU} / \mathrm{g}$ dry foliage and disease severity ratings 6 wpi data showed a highly significant effect of carrot accession on foliar severity ratings and population size of the pathogen detected $(P<0.0001)$.

$X h c$ was recovered from every inoculated plant in 2013. The size of the $X h c$ population detected on inoculated plants 6 wpi averaged $\log _{10} 9.13 \pm 0.04 \mathrm{CFU} / \mathrm{g}$ dry foliage $\left(\log _{10}\right.$ 4.69 to $\log _{10} 11.11 \mathrm{CFU} / \mathrm{g}$ ) across all carrot accessions with an interquartile range of $\log _{10} 8.47$ to $\log _{10} 10.09 \mathrm{CFU} / \mathrm{g}$ (Table 3; Fig. 2B). The pathogen was not detected on eight of 50 non-inoculated control plants. For 18 of these control plants, Xhc population averaged $\log _{10} 4.000 \mathrm{CFU} / \mathrm{g}$ or less dry foliage; for the other 24 control plants, the population ranged from $\log _{10} 4.059$ to $\log _{10}$ 8.110 CFU/g dry foliage. Similar to the 2012 screening, bacterial blight symptoms did not appear until the $X h c$ population was greater than $\log _{10} 6.00 \mathrm{CFU} / \mathrm{g}$ dry foliage with a diminishing rate of increase in bacterial population as severity of symptoms increased (Fig. 1B). Foliar ratings 3, 4, and 6 wpi for all accessions were highly significantly correlated $(P<0.0001)$ with $X h c$ population size detected 6 wpi with $r=0.56,0.57$, and 0.62 , respectively (Table 5). The eight resistant PI lines selected in 2012 averaged $\log _{10} 7.817 \pm$ $0.102 \mathrm{CFU} / \mathrm{g}$ dry foliage $\left(\log _{10} 4.794\right.$ to $\log _{10}$ $10.579 \mathrm{CFU} / \mathrm{g}) 6 \mathrm{wpi}$, whereas the five susceptible PI lines selected averaged $\log _{10}$ $9.538 \pm 0.081 \mathrm{CFU} / \mathrm{g}\left(\log _{10} 5.163\right.$ to $\log _{10}$ $11.052 \mathrm{CFU} / \mathrm{g}$ ); and the 12 commercial cultivars and 12 carrot wild relatives averaged $\log _{10} 9.577 \pm 0.068$ and $\log _{10} 9.223 \pm 0.069$ CFU/g, respectively (Fig. 2B). PI 187237, PI 357984 , and CEC1 WA averaged Xhc populations of $\log _{10} 8.91 \pm 0.31, \log _{10} 9.73 \pm$ $0.08 \%$, and $\log _{10} 8.17 \pm 0.17$, respectively, which ranked 14, 27, and seven of the 42 entries, respectively (Table 3 ).

The size of the Xhc population recovered 6 wpi was highly significantly correlated with foliar disease severity rated 2, 3, 4, and 6 wpi for all accessions evaluated in $2013(r=0.46$, $0.56,0.57$, and 0.62 , respectively) (Table 5). Spearman's correlation coefficients for $X h c$ population vs. disease severity ratings 3 and 4 wpi were not significant for the two inbred lines (data not shown), but was significant for the 6 wpi rating $(r=0.57$ at $P<0.0001)$.

The putative resistant and susceptible PI lines selected from the 2012 screening had similar reactions to $X h c$ in the 2013 screening, although average disease severity ratings for some PI lines were greater in 2013 than in 2012. In 2013, plants of the cultivar Nunhems 2-1 had the least severe mean foliar blight rating 6 wpi $(0.4 \% \pm 0.2 \%)$, which was similar statistically to the foliar ratings of PI 418967 and PI 432906; and the second smallest population of $X h c$ recovered $\left(\log _{10} 6.873\right.$ $\pm 0.120 \mathrm{CFU} / \mathrm{g}$ ), which was similar statistically to that of PI lines 263601,418967 , 432905 , and 432906 and the wild relative Ames 7674 (Table 3). Like in the 2012 screening, the resistant selection PI 418967 had the least $X h c$ recovered from foliage $\left(\log _{10} 6.250 \pm 0.164 \mathrm{CFU} / \mathrm{g}\right.$ dry foliage $)$ (Fig. 3B). This PI had the second least severe foliar blight 6 wpi $(1.8 \% \pm 0.4 \%)$ (Table 3$)$. Among the resistant PI lines selected, PI 263601 had the narrowest interquartile range in 2013 and averaged $\log _{10} 7.613 \pm 0.185$ $\mathrm{CFU} / \mathrm{g}$, whereas PI 163238 had the broadest interquartile range and averaged $\log _{10} 8.003$ $\pm 0.327 \mathrm{CFU} / \mathrm{g}$ (Fig. 3B). The other six resistant selections, PI lines 176969, 177381, 432905, 418967, 432906, and 436674, averaged $\log _{10} 9.184 \pm 0.166, \log _{10} 9.314 \pm 0.207$, $\log _{10} 7.160 \pm 0.191, \log _{10} 6.250 \pm 0.164, \log _{10}$ $7.157 \pm 0.208$, and $\log _{10} 8.167 \pm 0.210 \mathrm{CFU} / \mathrm{g}$, respectively (Fig. 3B).

Among the five susceptible PI lines selected, PI 390887 had the greatest disease severity rating 6 wpi $(44.8 \% \pm 4.2 \%)$, which 
Table 5. Spearman's correlation coefficient, $r$ (and associated $P$ value), between different ratings of foliar bacterial blight severity measured weekly and between disease ratings and population sizes of Xanthomonas hortorum pv. carotae quantified on carrot foliage in a 2013 greenhouse screening of 15 carrot PI lines from a 2012 greenhouse screening as well as 12 carrot cultivars, two inbred male-sterile lines, and 13 carrot wild relatives.

\begin{tabular}{|c|c|c|c|c|}
\hline \multirow[b]{2}{*}{ Carrot entries } & \multirow{2}{*}{$\begin{array}{l}\text { Foliar disease } \\
\text { severity rating }\end{array}$} & \multicolumn{2}{|c|}{ Foliar disease severity rating $z$} & \multirow{2}{*}{ 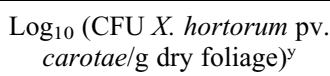 } \\
\hline & & 4 wpi & $6 \mathrm{wpi}$ & \\
\hline \multirow[t]{3}{*}{$\overline{\text { All entries }}{ }^{\mathrm{x}}$} & 3 wpi & $0.82 * * * \mathrm{t}$ & $0.53 * * *$ & $0.56^{* * *}$ \\
\hline & 4 wpi & - & $0.53 * * *$ & $0.57 * * *$ \\
\hline & 6 wpi & - & - & $0.62 * * *$ \\
\hline \multirow[t]{3}{*}{ PI lines ${ }^{w}$} & 3 wpi & $0.84 * * *$ & $0.62 * * *$ & $0.74 * * *$ \\
\hline & 4 wpi & - & $0.58^{* * *}$ & $0.68 * * *$ \\
\hline & 6 wpi & - & - & $0.59 * * *$ \\
\hline \multirow[t]{3}{*}{ Cultivars $^{v}$} & 3 wpi & $0.84 * * *$ & $0.54 * * *$ & $0.51 * * *$ \\
\hline & 4 wpi & - & $0.57 * * *$ & $0.53 * * *$ \\
\hline & 6 wpi & - & - & $0.65^{* * *}$ \\
\hline \multirow[t]{3}{*}{ Carrot wild relatives $^{u}$} & 3 wpi & $0.80 * * *$ & $0.40^{* *}$ & $0.33^{*}$ \\
\hline & 4 wpi & - & $0.47 * * *$ & $0.45^{* * *}$ \\
\hline & 6 wpi & - & - & $0.49^{* * *}$ \\
\hline
\end{tabular}

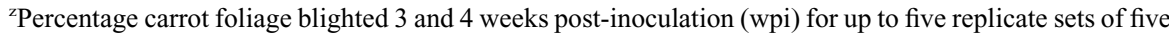
plants/line and 6 wpi for up to five replicate blocks of five carrot plants/line after the foliage was inoculated with $X$. hortorum pv. carotae as described in the main text.

${ }^{\mathrm{y}} X$. hortorum pv. carotae population detected on carrot foliage 6 wpi of up to five replications of five carrot plants/line, as described in the main text.

${ }^{\mathrm{x}} \mathrm{N}=201$ entries rated 3 and 4 wpi for percentage foliage blighted; and $\mathrm{N}=951$ plants evaluated for percentage foliage blighted and $X$. hortorum pv. carotae population detected on carrot foliage 6 wpi.

${ }^{\mathrm{w}} \mathrm{N}=75$ entries rated 3 and 4 wpi for percentage foliage blighted; and $\mathrm{N}=355$ plants evaluated for percentage foliage blighted and $X$. hortorum pv. carotae population detected on carrot foliage 6 wpi.

${ }^{v} \mathrm{~N}=60$ entries rated 3 and 4 wpi for percentage foliage blighted; and $\mathrm{N}=296$ plants evaluated for percentage foliage blighted and $X$. hortorum pv. carotae population detected on carrot foliage 6 wpi. ${ }^{u} \mathrm{~N}=56$ entries rated 3 and 4 wpi for percentage foliage blighted; and $\mathrm{N}=250$ plants evaluated for percentage foliage blighted and $X$. hortorum pv. carotae population detected on carrot foliage 6 wpi. ${ }_{\mathrm{t}}^{\mathrm{NS}}=$ nonsignificant at $P \leq 0.05 ; *{ }^{*}$, , and $* * *$ significant at $P=0.01,0.001$, and 0.0001 , respectively. $\mathrm{CFU}=$ colony-forming units.

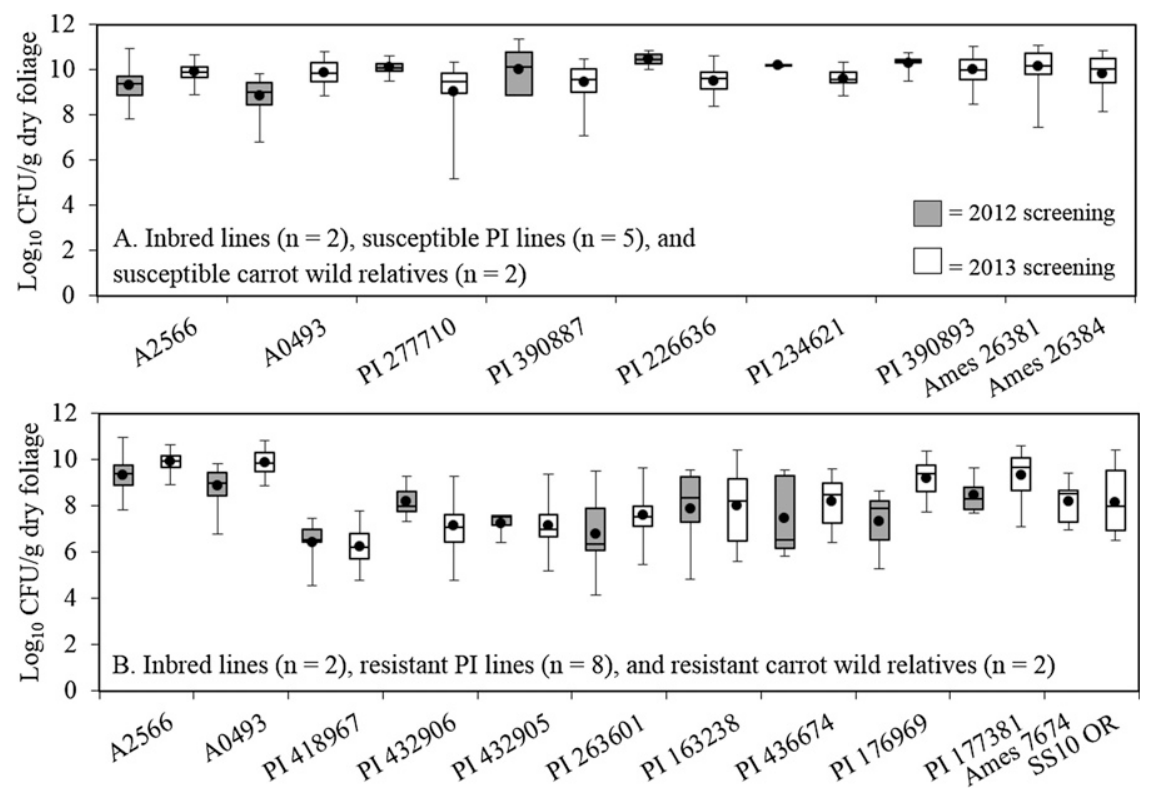

Fig. 3. (A) Population of Xanthomonas hortorum pv. carotae detected on the foliage of inbred male-sterile carrot lines (A2566 and A0493) as well as five carrot PI lines and two wild relatives (Ames 26381 and 26384) selected as putatively susceptible to this pathogen in 2012 and 2013 greenhouse screenings; and (B) on the foliage of the same two inbred male-sterile lines compared with eight PI lines and two wild relatives (Ames 7674 and SS10 OR) selected as putatively resistant to this pathogen. The carrot wild relatives were screened only in 2013. The black dot for each group represents the mean, the horizontal line in each box represents the median, the upper and lower ends of each box represent the first and third quartiles, respectively, and the whiskers represent the range in pathogen population size detected.

was similar statistically to that of PI 390893 and Nunhems 2-2 (Table 3). This PI had a similar mean population of $X h c$ recovered $\left(\log _{10} 9.481 \pm 0.172 \mathrm{CFU} / \mathrm{g}\right.$ dry foliage) to that of 16 other accessions evaluated in 2013. Nunhems 2-2 had the greatest mean $X h c$ population detected $\left(\log _{10} 10.407 \pm 0.066\right.$ $\mathrm{CFU} / \mathrm{g}$ ) and was among the entries with the most severe foliar ratings 6 wpi (mean of $24.8 \% \pm 1.5 \%$ foliage-blighted, which was similar statistically to ratings for PI lines 234621, 390893, and 390887 as well as Nunhems 2-3) (Table 3). Of these five highly susceptible PI lines, PI 234621 had the narrowest interquartile range of $\log _{10} 9.425$ to $\log _{10} 9.896 \mathrm{CFU} / \mathrm{g}$ dry foliage with an average $\log _{10} 9.622 \pm 0.066 \mathrm{CFU} / \mathrm{g}$ (Fig. 3A). The other four, PI lines 226636, 277710, 390887, and 390893, had average Xhc populations ranging from $\log _{10} 9.055 \pm 0.296$ to $\log _{10}$ $10.001 \pm 0.138 \mathrm{CFU} / \mathrm{g}$ (Fig. 3A).

\section{Discussion}

Results of this greenhouse study in which carrot accessions were inoculated with $X h c$ indicate that significant differences in resistance exist among PI lines from the USDA NPGS carrot germplasm collection. Symptoms of bacterial blight were observed on almost all inoculated plants of the 103 carrot accessions tested in 2012 and 2013, and Xhc was recovered from every inoculated plant, demonstrating that none of the accessions had complete resistance to this pathogen. However, the severity of bacterial blight symptoms and the amount of Xhc recovered from the foliage varied significantly among the accessions tested. The greatest level of resistance was identified in four PI lines (263601, 418967, 432905, and 432906) as well as two carrot wild relatives (Ames 7674 and SS10 OR). Based on disease severity ratings and size of the $X h c$ population detected on the foliage, PI 418967 and PI 432906 had comparable reactions to $X h c$ as Nunhems 2-1, a proprietary cultivar specifically developed for resistance to Xhc. Nunhems 2-1 had the least severe bacterial blight in this study, although PI 418967 and PI 432906 had statistically similar bacterial blight severity ratings. Significantly less $X h c$ was recovered from the foliage of these two PI lines, in addition to PI 263601 and PI 432905, than from foliage of the other 11 commercial carrot cultivars tested. The smallest mean Xhc population was recovered from plants of PI 418967, although plants of Nunhems 2-1, PI 432905, and PI 432906 had statistically similar populations.

Based on correlation coefficients for foliar disease ratings vs. population of Xhc detected on the foliage, evaluating disease severity 4 wpi for up to five plants/carrot line was approximately as effective at predicting the amount of $X h c$ on the foliage as disease severity ratings 6 wpi on individual plants. Rating groups of plants for severity of bacterial blight were more efficient than evaluating individual plants, particularly for the 2012 resistance screening with a large number of entries. Furthermore, consistent detection of highly significant correlations between foliar disease ratings done $\approx 2$ weeks before quantifying $X h c$ and population of $X h c$ detected on the foliage illustrates that it should be possible to screen large numbers of carrot entries using foliar ratings instead of the highly resource- and labor-intensive $X h c$ 
quantification protocol. Regardless, an adequate number of replications of entries is necessary for accurate assessment of the reaction of accessions to Xhc. For example, the 2013 trial entailed a more robust experimental design than the 2012 trial, which facilitated more effective identification of those accessions that supported more limited growth of $X h c$ than in the 2012 trial. PI lines 176969 and 177381 had the third and eighth least amount of $X h c$ recovered from foliage out of 85 accessions screened in 2012, respectively, but had the 15th and 20th least amount of $X h \mathrm{c}$ recovered out of 42 accessions screened in 2013, respectively. The putative resistance of these lines identified in 2012 may have been inaccurate as a result of limited space to accommodate almost twice as many entries in 2012 vs. 2013. However, all highly susceptible selections from the 2012 screening were similarly susceptible in the 2013 screening.

Bacterial blight symptoms were not observed on plants with $X h c$ populations less than $\log _{10} 6.00 \mathrm{CFU} / \mathrm{g}$ dry foliage, and the bacterial population increased the more severe the symptoms, but at a diminishing rate. This is consistent with prior observations of the epiphytic nature of colonization of carrot foliage by Xhc (du Toit et al., 2005; Gilbertson, 2002). For example, bacterial blight severity ratings 6 wpi ranged from $\approx 1 \%$ to $3 \%$ on plants from which $X h c$ populations recovered ranged from $10^{6}$ and $10^{7} \mathrm{CFU} / \mathrm{g}$ dry foliage, whereas plants with $5 \%$ to $10 \%$ severity ratings 6 wpi had $X h c$ populations of $10^{7}$ to $10^{9} \mathrm{CFU} / \mathrm{g}$ dry foliage, and plants with greater than $10 \%$ bacterial blight severity had Xhc populations of $10^{9}$ to $10^{10} \mathrm{CFU} / \mathrm{g}$ dry foliage. The more robust sampling of five replicate blocks of five plants/line in the 2013 screening enabled more robust calculation of the correlation between Xhc population and foliar disease severity than in the 2012 screening $(r=0.52$ at $P<0.0001$ in 2012 vs. $r=0.62$ at $P<0.0001$ in 2013). These results further illustrate the diminishing rate of increase in pathogen population with increasing severity of symptoms.

In 2012, one replicate of non-inoculated control plants of the inbred line A2566 had relatively large populations of $X h c$ recovered from the foliage (greater than $10^{7} \mathrm{CFU} / \mathrm{g}$ dry foliage) of three of the five plants tested. In 2013, populations greater than $10^{7} \mathrm{CFU} / \mathrm{g}$ dry foliage were recovered from only one noninoculated replicate of control plants of each of the two inbred lines. Detection of the pathogen on these control plants demonstrated that some spread of Xhc may have occurred among entries in the trial or the seed of these inbreds may have been infested with $X h c$ before planting. However, the majority of non-inoculated control plants were not colonized by $X h c$ in either trial, indicating that cross-contamination was unlikely to have influenced the results adversely. Assays for detection of $X h c$ on carrot seed of the PI lines tested in this study were not carried out because of the very small amount of seed provided by the USDA NPGS (200 seeds/ line). Although $X h c$ inoculum could have been present on some of the seed planted, bacterial blight symptoms were not observed on any of the plants before inoculation with $X h c$ in each of the 2012 and 2013 trials, and symptoms of bacterial blight did not develop until 2 to 3 wpi in both trials. Therefore, it is unlikely that seedborne inoculum was a significant factor in development of bacterial blight in these trials. If possible, hot water treatment of seed lots could be used to reduce the potential of seedborne $X h c$ confounding inoculum applied to the foliage. Seed treatment was not used in this study because of the very limited amount of seed available and the risk of a seed treatment reducing seed germination, vigor, or shelf life.

Multiple genes may be associated with resistance to $X h c$ in carrot accessions based on resistance detected in other plant species to various Xanthomonas pathogens (e.g., Jones et al., 2002; Scott et al., 1995, 2001; Stall et al., 2009; Yang et al., 2005). In various disease resistance screening studies (Jones et al., 2002; Scott et al., 1995, 2001; Yang et al., 2005), symptoms caused by Xanthomonas pathogens observed on a range of resistant to susceptible pepper and tomato plants were highly variable, similar to what was observed in this study. Four genes have been described in tomato and five genes in pepper that contribute to hypersensitive reactions to $X$. vesicatoria, $X$. euvesicatoria, $X$. perforans, and $X$. gardneri (Stall et al., 2009). It is possible the resistant carrot accessions identified in this study may have similar genetic mechanisms of resistance to $X h c$.

For seven of the 12 carrot wild relatives assayed in 2013, greater than $20 \%$ of the plants senesced before disease severity ratings and $X h c$ populations could be determined because of annual or ephemeral nature of these accessions under the conditions of this study. Ames 7674 and SS10 OR were among the 10 entries with the smallest population of $X h c$ detected on the foliage, but only 13 and 10 plants of these entries were assayed, respectively, because of the difficulty of working with such ephemeral lines. Daucus spp. of this nature should be inoculated and evaluated sooner after planting than in this trial to assess effectively the response of these lines to Xhc. Other ephemeral entries screened in this study included Ames 30214, 29107, and 29098; RDC 5 WI; and SS10 WI.

The carrot inbred lines A2566 and A0493 had less variation in the size of $X h c$ population recovered from the foliage, particularly in the more robust 2013 screening, compared with the resistant and susceptible PI lines selected. This was expected given the PI lines are likely more heterogeneous than inbred lines with genetic uniformity of A2566 and A0493 resulting from four generations of inbreeding with close sibling mating and 12 generations of inbreeding, respectively (Simon et al., 1987, 1990). However, PI 226636 and PI 234621 also had relatively narrow interquartile ranges for $X h c$ population sizes recovered from the foliage. Regardless, care should be taken when using PI lines to develop resistance to bacterial blight because individual plants within a PI line may differ in response to $X h c$.

Foliage morphology varied among the carrot PI lines evaluated in this study, from fused to lace-like leaflets, with varying degrees of pubescence of the foliage. Plants of each accession were assessed for foliage color and rated for degree of pubescence on a scale of 0 to 5 , where $0=$ no pubescence and 1 to 5 represent incrementally more pubescent foliage (data not shown). Foliage color did not appear to be correlated with severity of bacterial blight or population size of $X h c$ recovered. However, the most susceptible PI line to $X h c$ in 2013, PI 390893, and two carrot wild relatives, Ames 26381 and 26384, had some of the most pubescent foliage (average score of 3.5) compared with the most resistant lines, PI 418967, PI 432905, and PI 432906 (average pubescence score of 1.0).

In conclusion, this study identified carrot PI lines that differ in response to $X h c$ and illustrates that the carrot PI collection offers a valuable public source of resistance for carrot breeders to develop bacterial blightresistant cultivars. In comparison with the only resistant proprietary carrot cultivar evaluated in this trial, Nunhems 2-1, PI lines 263601, 418967, 432905, and 432906, and the carrot wild relative Ames 7674 had equivalent resistance to $X h c$, whether measured as pathogen population recovered from the foliage or severity of bacterial blight in the 2013 screening. These PI lines could be used to develop resistant cultivars by backcrossing the resistance into commercially acceptable genetic backgrounds, e.g., as done by Ellis (1999) for carrot rust fly resistance. Each of the carrot cultivars evaluated in this study, except Nunhems 2-1, was moderately to highly susceptible to Xhc. PI lines 390887 and 390893 as well as Ames 26381, 26384, and 30198 were among the most susceptible entries to $X h c$. The susceptible lines could be used along with resistant PI lines to determine the nature of inheritance of $X h c$ resistance in carrot, e.g., as done by Scott et al. (2001) for resistance in tomato to bacterial spot caused by $X$. campestris pv. vesicatoria. This would enhance efforts to breed for bacterial blight resistance. Development of carrot cultivars with resistance to $X h c$ will provide the carrot seed industry and carrot growers with additional options for management of bacterial blight.

\section{Literature Cited}

Boiteux, L.S. and P.W. Simon. 2002. Breeding for disease resistance in carrots, p. 7-8. In: Davis, R.M. and R.N. Raid (eds.). Compendium of umbelliferous crop diseases. American Phytopathological Society, St. Paul, MN

Butler, M. and R. Simmons. 2012. 2012 agricultural statistics: Central Oregon. Oregon State University, Corvallis, OR. 15 Apr. $2014<\mathrm{http} / /$ oregonstate.edu/dept/coarc/sites/default/files/ 2012_agricultural_statistics-coarc.pdf $>$.

Christianson, C.E. 2014. Screening carrot germplasm for resistance to Xanthomonas hortorum 
pv. carotae. MS thesis, Washington State University, Pullman, WA.

Crowe, F., M. Butler, R. Simmons, C. Campbell, C. Weber, J. Weber, M. Weber, B. Holliday, and J. Klauzer. 2005. Reduced Xanthomonas and increased seed germination from carrot seed crops irrigated by drip vs. sprinkler, 2004 and 2005. Oregon State University Central Oregon Agricultural Research Center. 26 Mar. 2014. $<$ http://oregonstate.edu/dept/coarc/sites/default/ files/publication/05_carrot_drip_sprinkler.pdf $>$.

du Toit, L.J., F.J. Crowe, M.L. Derie, R.B. Simmons, and G.Q. Pelter. 2005. Bacterial blight in carrot seed crops in the Pacific Northwest. Plant Dis. 89:896-907.

du Toit, L.J. and M.L. Derie. 2005. Evaluation of Actigard, bactericides, and compost teas for control of bacterial blight in carrot seed crops, 2004. Fungic. Nematic. Tests 60:V046.

du Toit, L.J., M.L. Derie, and N. Lloyd. 2006. Evaluation of Actigard, bactericides, and compost teas for control of bacterial blight in carrot seed crops, 2005. Fungic. Nematic. Tests 61: V042.

du Toit, L.J. and M.L. Derie. 2008a. Effect of inoculum concentration and timing of ManKocide application on bacterial blight of carrot, 2007. Plant Dis. Mgt. Rpt. 2:V008.

du Toit, L.J. and M.L. Derie. 2008b. Evaluation of Tanos and copper bactericides for control of bacterial blight of carrot, 2007. Plant Dis. Mgt. Rpt. 2:V009.

du Toit, L.J., R.L. Gilbertson, M. Asma, and N.W. Schaad. Detection of Xanthomonas hortorum pv. carotae in carrot seeds. In: APS manual on detection of plant pathogenic bacteria in seed and planting material. (In press.).

Ellis, P.R. 1999. The identification and exploitation of resistance in carrots and wild Umbelliferae to the carrot fly, Psil rosae (F.). Integrated Pest Mgt. Rev. 4:259-268.

Gilbertson, R.L. 2002. Bacterial leaf blight of carrot, p. 11-12. In: Davis, R.M. and R.N. Raid (eds.). Compendium of umbelliferous crop diseases. American Phytopathological Society, St. Paul, MN.

Gugino, B.K., J. Carroll, J. Chen, J. Ledwig, and G. Abawi. 2004. Carrot leaf blight diseases and their management in New York. Cornell Cooperative Extension, Cornell, NY. 19 Mar. 2014.
$<$ http://www.nysipm.cornell.edu/factsheets/ vegetables/misc/clb.pdf $>$.

Jones, J.B., G.V. Minsavage, P.D. Roberts, R.R Johnson, C.S. Kousik, S. Subramanian, and R.E. Stall. 2002. A non-hypersensitive resistance in pepper to the bacterial spot pathogen is associated with two recessive genes. Phytopathology 92:273-277.

Kado, E.I. and M.G. Heskett. 1970. Selective media for isolation of Agrobacterium, Corynebacterium, Erwinia, Pseudomonas, and Xanthomonas. Phytopathology 60:969-976.

Kimbrell, J.A., S.A. Givani, T.N. Temple, K.B Johnson, and J.H. Chang. 2011. Genome sequencing and comparative analysis of the carrot bacterial blight pathogen, Xanthomonas hortorum pv. carotae M081, for insights into pathogenicity and applications in molecular diagnostics. Mol. Plant Pathol. 12:580-594.

Leite, R.P., G.V. Minsavage, U. Bonas, and R.E. Stall. 1994. Detection and identification of phytopathogenic Xanthomonas strains by amplification of DNA sequences related to the hrp genes of Xanthomonas campestris pv. vesicatoria. Appl. Environ. Microbiol. 60:1068-1077.

Pfleger, F.L., G.E. Harman, and G.A. Marx. 1974 Bacterial blight of carrots: Interaction of temperature, light, and inoculation procedures on disease development of various carrot cultivars. Phytopathology 64:746-749.

Reitsma, K.R. and L.D. Clark. 2013. Daucus germplasm collection at the North Central Regional Plant Introduction Station. 36th Internat. Carrot Conf., 15-16 Aug. 2013, Madison, WI (abstr.). 2 Jan. 2014. <http://www.vcru.wisc. edu/simonlab/carrotconference/program.htm>.

Rogers, P.M., W.R. Stevenson, J.A. Wyman, K. Frost, and R. Groves. 2011. IPM perspectives for carrot foliage diseases in Wisconsin. University of Wisconsin Extension Bulletin No. A3945. Madison, WI.

Rubatzky, V.E., C.F. Quiros, and P.W. Simon. 1999. Carrots and related Umbelliferae. Crop Production Science in Horticulture Series No. 10. CABI Publishing, New York, NY.

Schaad, N.V. 1988. Laboratory guide for identification of plant pathogenic bacteria. 2nd Ed. American Phytopathological Society, St. Paul, MN.

Scott, J.W., J.B. Jones, and G.C. Somodi. 2001. Inheritance of resistance in tomato to race $\mathrm{T} 3$ of the bacterial spot pathogen. J. Amer. Soc. Hort. Sci. 126:436-441.

Scott, J.W., J.B. Jones, G.C. Somodi, and R.E. Stall. 1995. Screening tomato accessions for resistance to Xanthomonas campestris pv. vesicatoria, race T3. HortScience 30:579581.

Simon, P.W., C.E. Peterson, M.J. Bassett, J.O Strandberg, J.M. White, and V.E. Rubatzky. 1987. B2566 carrot inbred. HortScience 22:327.

Simon, P.W., C.E. Peterson, and W.H. Gableman. 1990. B493 and B9304, carrot inbreds for use in breeding, genetics, and tissue culture. HortScience 25:815.

Stall, R.E., J.B. Jones, and G.V. Minsavage. 2009. Durability of resistance in tomato and pepper to Xanthomonads causing bacterial spot. Annu. Rev. Phytopathol. 47:265-284

Temple, T.N., L.J. du Toit, M.L. Derie, and K.B. Johnson. 2013. Quantitative molecular detection of Xanthomonas hortorum pv. carotae in carrot seed before and after hot-water treatment. Plant Dis. 97:1585-1592.

Umesh, K.C., R.M. Davis, and R.L. Gilbertson. 1998. Seed contamination thresholds for development of carrot bacterial blight caused by Xanthomonas campestris pv. carotae. Plant Dis. 82:1271-1275.

U.S. Department of Agriculture National Agricultural Statistics Service. 2014. Vegetables 2013 summary. National Agricultural Statistics Service, USDA. 15 Apr. 2014. <http://usda. mannlib.cornell.edu/usda/current/VegeSumm/ VegeSumm-03-27-2014.pdf>.

Washington State Commission on Pesticide Registration. 2011. Carrot Seed. Washington State Commission on Pesticide Registration Compendium of Washington Agriculture. 18 Mar 2014. <http://69.93.14.225/wscpr/LibraryDocs/ Carrotseedversion2lw.pdf $>$.

Williford, R.E. and N.W. Schaad. 1984. Agar medium for selective isolation of Xanthomonas campestris pv. carotae from carrot seeds. Phytopathology 74:1142 [abstr.].

Yang, W., E.J. Sacks, M.L. Lewis Ivey, S.A. Miller, and D.M. Francis. 2005. Resistance in Lycopersicon esculentum intraspecific crosses to race T1 strains of Xanthomonas campestris pv. vesicatoria causing bacterial spot of tomato. Phytopathology 95:519-527. 